\title{
Clinical and Radiological Classification of the Jawbone Anatomy in Endosseous Dental Implant Treatment
}

\author{
Gintaras Juodzbalys ${ }^{1}$, Marius Kubilius ${ }^{1}$ \\ ${ }^{1}$ Department of Maxillofacial Surgery, Lithuanian University of Health Sciences, Kaunas, Lithuania.
}

\author{
Corresponding Author: \\ Gintaras Juodzbalys \\ Vainiku 12 \\ LT- 46383, Kaunas \\ Lithuania \\ Phone: +37037297055 \\ Fax: +37037323153 \\ E-mail: gintaras@stilusoptimus.lt
}

\begin{abstract}
Objectives: The purpose of present article was to review the classifications suggested for assessment of the jawbone anatomy, to evaluate the diagnostic possibilities of mandibular canal identification and risk of inferior alveolar nerve injury, aesthetic considerations in aesthetic zone, as well as to suggest new classification system of the jawbone anatomy in endosseous dental implant treatment.

Material and Methods: Literature was selected through a search of PubMed, Embase and Cochrane electronic databases. The keywords used for search were mandible; mandibular canal; alveolar nerve, inferior; anatomy, cross-sectional; dental implants; classification. The search was restricted to English language articles, published from 1972 to March 2013. Additionally, a manual search in the major anatomy and oral surgery books were performed. The publications there selected by including clinical and human anatomy studies.

Results: In total 109 literature sources were obtained and reviewed. The classifications suggested for assessment of the jawbone anatomy, diagnostic possibilities of mandibular canal identification and risk of inferior alveolar nerve injury, aesthetic considerations in aesthetic zone were discussed. New classification system of the jawbone anatomy in endosseous dental implant treatment based on anatomical and radiologic findings and literature review results was suggested.

Conclusions: The classification system proposed here based on anatomical and radiological jawbone quantity and quality evaluation is a helpful tool for planning of treatment strategy and collaboration among specialists. Further clinical studies should be conducted for new classification validation and reliability evaluation.
\end{abstract}

Keywords: mandible; alveolar nerve, inferior; anatomy, cross-sectional; dental implants; classification.

Accepted for publication: 12 June 2013

To cite this article:

Juodzbalys G, Kubilius M. Clinical and Radiological Classification of the Jawbone Anatomy in Endosseous Dental Implant Treatment.

URL: http://www.ejomr.org/JOMR/archives/2013/2/e2/v4n2e2ht.pdf

doi: $10.5037 /$ jomr.2013.4202 


\section{INTRODUCTION}

After the loss of teeth atrophy of the alveolar processes occurs in a vertical as well as a horizontal plane. The term atrophy is defined in the dictionary as "a wasting away; a diminution in the size of a cell, tissue, organ, or part" [1]. This process is starting and continuous throughout life because of the lack of stimuli (disuse atrophy) seen on alveolar process of the jaws [2].

Dental implants have become the most popular and reliable treatment option for restoring missing teeth. Nowadays there is a wide choice of screw-type implant systems. The success of dental implants depends on the jawbone quantity and quality [3] . Therefore, it is important to measure the alveolar process precisely so that the proper system may be chosen [4]. There are number of classifications suggested for assessment of the degree of atrophy of partially or fully edentulous jaws [5-11]. One of the most popular classification systems for jaw anatomy (jaw shape and quality) for dental implant treatment was proposed by Lekholm and Zarb in 1985 [12]. However, this classification, like many others, described changes only of jaw shapes in general and failed to indicate precise measurements [13]. Juodzbalys et al. in 2004 [14] proposed clinical and radiological classification of the jawbone anatomy for implantation based on edentulous jaw dental segment (eJDS) anatomy assessment. Nevertheless, this classification fails to assess mandibular canal anatomy variations and risk degree of inferior alveolar nerve injury. By means of the advancement of radiographic technology, i.e. development of cone beam computed tomography (CBCT), diagnostic possibilities are more precise, especially in the case of mandibular canal assessment [15-17]. In view of these considerations the purpose of present article was to review the classifications suggested for assessment of the jawbone anatomy, to evaluate the diagnostic possibilities of mandibular canal identification and risk of inferior alveolar nerve injury, aesthetic considerations in aesthetic zone, as well as to suggest new classification system of the jawbone anatomy in endosseous dental implant treatment.

\section{MATERIAL AND METHODS}

Literature was selected through a search of PubMed, Embase and Cochrane electronic databases. The keywords used for search were mandible; mandibular canal; alveolar nerve, inferior; anatomy, cross-sectional; dental implants; classification. The search was restricted to English language articles, published from 1972 to March 2013. Additionally, a manual search in the major anatomy and oral surgery books were performed. The publications there selected by including clinical and human anatomy studies.

\section{RESULTS \\ Classifications of jawbone anatomy}

It was mentioned above that the most popular classification systems for jaw anatomy (jaw shape and quality) for dental implant treatment was proposed by Lekholm and Zarb [12]. The quantity of jawbone is divided into five groups, based on residual jaw shape following tooth extraction. There are presented drawings of the jaws - jaw cross-sections, accompanied by text, and assessment methods. Similarly Cawood and Howell's [9] ridge classification presented as alveolar process resorption level jaw cross-sections and text. During all stages of the alveolar ridge atrophy, characteristic shapes result from the resorptive process. The biggest shortcoming of previous classifications [5-11] is fact, that those classifications are twodimensional representations and do not show the three-dimensionality of atrophic ridges. Nowadays clinician can combine three-dimensional jawbone assessment and image-guided surgery by means of CBCT. Diagnostic and planning software are available to assist in implant planning to create diagnostic and surgical implant guidance stents (e.g., Virtual Implant Placement, Implant Logic Systems, Cedarhurst, USA; Simplant, Materialise, Belgium; Easy Guide, Keystone Dental, USA) [18].

Misch and Judy [19] classified available bone into 4 divisions: abundant, barely sufficient, compromised, and deficient (A-D). Abundant bone requires no augmentation and is greater than $5 \mathrm{~mm}$ in width, 10 to $13 \mathrm{~mm}$ in height, and $7 \mathrm{~mm}$ in length. Barely sufficient bone is 2.5 to $5 \mathrm{~mm}$ in width, greater than 10 to $13 \mathrm{~mm}$ in height, and greater than $12 \mathrm{~mm}$ in length and can be modified with osteoplasty or augmentation of hard or soft tissues, depending on the nature of the defect (B-w). Compromised bone necessitates osteoplasty and some form of hard or soft tissue augmentation depending on the extent of the defect in height (less than $10 \mathrm{~mm}, \mathrm{C}-\mathrm{h}$ ) or width (less than $2.5 \mathrm{~mm}, \mathrm{C}-\mathrm{w}$ ). Deficient bone requires substantial hard tissue augmentation from extraoral sites and is generally not amenable to implant rehabilitation. Unfortunately, aesthetic component in this classification is not considered. Implant rehabilitation is no longer just a vehicle to restore lost masticatory and phonetic function. It has become an integral part of modern implant dentistry for achieving structural and aesthetic pleasing outcomes [20]. It is well established that 
the soft tissue appearance is largely dependent upon the underlying bone topography [21]. Hence, it is important to assess hard tissue parameters, such as horizontal bone deficiency and interproximal bone height.

Current classifications also fail to assess mandibular canal anatomy variations and risk degree of inferior alveolar nerve injury. Worthington [22] showed that even after the accurate measurement of available bone, the nerve injury can occur as the result of over penetration of the drill owing to low resistance of the spongy bone; this can lead to slippage of the drill even by experienced surgeons.

Lekholm and Zarb [12] classify quality of residual alveolar bones into four types: type $1=$ large homogenous cortical bone; type $2=$ thick cortical layer surrounding a dense medullar bone; type $3=$ thin cortical layer surrounding a dense medullar bone; type $4=$ thin cortical layer surrounding a sparse medullar bone). According to Ribeiro-Rotta et al. [23] and Bergkvist et al. [24] classification of quality of residual alveolar bones indicate a good correlation with bone mineral content. Trisi and Rao [25] proposed the system for bone quality assessment with three classes (dense, normal and soft bone).

Some authors proposed to evaluate jawbone density in presurgical planning [26-28]. It is possible to assess jawbone density using CT values (Hounsfield units: HU) and bone mineral densities obtained by medical CT. Norton and Gamble [27] measured the bone density in the posterior mandible using SimPlant software (3D Diagnostix, Boston, MA, USA) and concluded that the mean CT value was 669.6 HU. Misch [26] classified cancellous bone density into 5 grades: D1: $>1250 \mathrm{HU}$; D2: 850 to $1250 \mathrm{HU}$; D3: 350 to $850 \mathrm{HU}$; D4: 150 to $350 \mathrm{HU}$; and D5: < $150 \mathrm{HU}$. In the conversion of CT values (HU), the mean value in the molar region was $4.5 \times 102$ (D3): in the first molar region it was $5.2 \times 102$ (D3), in second molar region $4.3 \times 102$ (D3), and in the third molar region it was $0.7 \times 102$ (D5).

It is interesting to know that Başa and Dilek [29] assessed the risk of perforation of the mandibular canal by implant drill using density and thickness parameters. They investigated whether the resistance of the bone surrounding the mandibular canal had sufficient density and thickness to avoid perforation by implant drills. Study of the computed tomography (CT) images of 99 patients, showed that overall, average bone thickness in the premolar and molar regions was $0.87 \pm 0.18$ and $0.86 \pm 0.18 \mathrm{~mm}$, respectively, whereas the bone density in the premolar and molar regions was $649.18 \pm 241.42$ and $584.44 \pm 222.73 \mathrm{HU}$, respectively $(\mathrm{P}<0.001)$. It was concluded that the average density and thickness of the bone that surrounds the mandibular canal was not sufficient to resist the implant drill. Furthermore, in the posterior mandible, cancellous bone is more abundant and has bigger intratrabecular spaces and less dense than in anterior mandible $[30,31]$. In some cases with low density bone, the twist drills may drop into intratrabecular spaces during preparation thus leads to the displacement of the implants deeper than planned [32].

The measurements of bone density in designed sites are important in presurgical planning when using CBCT for dental implant treatment. However, the pixel or voxel values obtained from CBCT images are not absolute values. Naitoh et al. [33] demonstrated a high-level correlation between voxel values of $\mathrm{CBCT}$ and bone mineral densities of multislice CT $(r=0.965)$. They concluded that voxel values of mandibular cancellous bone in CBCT could be used to estimate bone density. In contrast, Nackaerts et al. [34] and Parsa et al. [35] determined the grey value variation at the implant site with different scan settings, including field of view (FOV), spatial resolution, number of projections, exposure time and dose selections in two CBCT systems and compared the results with those obtained from a multislice CT system. Authors concluded that grey-level values from CBCT images are influenced by device and scanning settings.

\section{Radiological examination}

The main goals of radiological jawbone examination are to determine the quantity, quality and angulations of bone, selection of the potential implant sites, and to verify absence of pathology. Clinician should choose proper radiographic method which provides sufficient diagnostic information with the least possible radiation dose.

Periapical radiographs have been used for many years to assess the jaws pre- and post-implant placement [흐] Periapical radiographs commonly are used to evaluate the status of adjacent teeth, remaining alveolar bone in the mesiodistal dimension and vertical height. The long cone paralleling technique for taking periapical X-ray is the technique of choice for the following reasons: reduction of radiation dose; less magnification; a true relationship between the bone height and adjacent teeth is demonstrated [37]. If the paralleling technique is not used, periapical radiographs create an image with foreshortening and elongation [38-40]. Nevertheless, the biggest concern of periapical radiographs is in $28 \%$ of patients that mandibular canal could not be clearly identified in the second premolar and first molar regions [41] and mandibular foramen can be identified around $47-75 \%$ cases [42].

When a specific region (maxillofacial area, including 
many of the vital structures, such as maxillary sinus, inferior alveolar nerve and nasal fossa) that is too large to be seen on a periapical view, panoramic radiograph can be the method of choice. The major advantages of panoramic images are the broad coverage of oral structures, low radiation exposure (about $10 \%$ of a fullmouth radiographs), and relatively inexpensiveness of the equipment. The major drawbacks of panoramic imaging are: lower image resolution, high distortion, and presence of phantom images [43]. For example, Naitoh et al. [33] found that mandibular canal visibility on panoramic radiographs in superior and inferior wall was only $36.7 \%$. Similarly, Lindh et al. [44] reported that the mandibular canal of specimen cadavers was clearly visible in $25 \%$ of panoramic radiographs (range 12 to $86 \%$ ). Klinge et al. [45] also reported that the mandibular canal of specimen cadavers was not visible in $36.1 \%$ of panoramic radiographs. The location and configuration of mandibular canal are important in imaging diagnosis for the proper dental implant placement in the mandible [46-48].

One of the most challenged regions for implantation in mandible is mental foramen region. This is because there are many variations with regards to the size, shape, location and direction of the opening of the mental foramen. After comparison of the anatomical and radiological assessment of 4 cadaver skulls, Yosue and Brooks [49] concluded that the panoramic and periapical films reflected the actual position of mental foramen in the skulls $<50 \%$ the time. Furthermore, Sonick et al. [50] found that the average linear errors occurred during routine bone assessments $(\mathrm{n}=12)$ for panoramic films were $24 \%$ (mean $3 \mathrm{~mm}$; range 0.5 to $7.5 \mathrm{~mm}$ ), for periapical films were $14 \%$ (mean $1.9 \mathrm{~mm}$; range 0.0 to $5.0 \mathrm{~mm}$ ) and only $1.8 \%$ (mean $0.2 \mathrm{~mm}$; range 0.0 to $0.5 \mathrm{~mm}$ ) for CT scans. Kuzmanovic et al. [51], Ngeow and Yuzawati [52] and Jacobs et al. [53] similarly concluded that panoramic radiograph is not sufficient for anterior loop detection and presurgical implant planning in the mental region and there is a need for other additional images.

Even incisive canal detection is complicated using panoramic radiography. For example, Jacobs with coworkers [54] reported that the mandibular incisive canal was identified only in $15 \%$ of the 545 panoramic radiographs, with good visibility of only $1 \%$. In contrast, canal was observed on $93 \%$ of CT scans with a good visibility in $22 \%$ of cases.

Peker et al. [55] showed that the measurements obtained from CT images are more consistent with direct measurements than the measurements obtained from panoramic radiographic images or conventional tomographic images. Furthermore, Rouas et al. [56] reported that the atypical mandibular canal such as bifid mandibular canal, in most cases can be identified using only three-dimensional imaging techniques. It was thought that the bifid mandibular canal is often left unrecognized [57]. Therefore, duplication or division of the canal by means of panoramic radiographs was found in about $1 \%$ of patients [58]. Naitoh et al. [59] reconstructed 122 two-dimensional images of the various planes in mandibular ramus region to the computer program using threedimensional visualization and measurement software. Bifid mandibular canal in the mandibular ramus region was observed even in $65 \%$ of patients.

When the periapical radiography, panoramic radiography, tomography, or CT were compared for their efficiency in the identification of the mandibular canal, the CBCT seems to have the most potential while reduces radiation exposure considerably [60]. Similarly, CT scans are more accurate than conventional radiographs in mental foramen and anterior loop detection $[\underline{45}, \underline{50}, \underline{53}, \underline{61}, \underline{62}]$. However, cross-sectional imaging have following limitations: limited availability, high cost and the need for image interpretation $[\underline{63}, 64]$. However, CBCT is often recommended for clinical usage, especially in cases there the vital structures are difficult to detect due to its high accuracy and low radiation exposure $[\underline{65}, \underline{66}, \underline{68}]$. The main advantage of CBCT is a low dose scanning system, which has been specifically designed to produce three-dimensional images of the maxillofacial skeleton. Hence, a major difference between $\mathrm{CT}$ and $\mathrm{CBCT}$ is how the data are gathered: $\mathrm{CT}$ acquires image data using rows of detectors, CBCT exposes the whole section of the patient over one detector $[69,70]$. Furthermore, CBCT permits not only diagnosis, it facilitates image-guided surgery [18].

\section{Inferior alveolar nerve injury risk}

Inferior alveolar nerve injury is a serious complication with incidence ranged from 0 to $40 \%$ [71-87]. As a result, many important functions such as speech, eating, kissing, make-up application, shaving and drinking were affected [77]. This influences patient's quality of life and often resulted in negative psychological adverse effects [79]. The most common causes of iatrogenic inferior alveolar nerve injuries are discrepancies of radiographs, surgeon's mistakes, low resistance of mandibular spongy bone and lack of mandibular canal superior wall.

The most severe types of injuries are caused by implant drills and implants themselves [22]. Many implant drills are slightly longer, for drilling efficiency, than their corresponding implants. Implant drill length varies and must be understood by the surgeon because the specified length may not reflect an additional millimetre so called 
"y" dimension [84]. Lack of knowledge about this may cause avoidable complications [88]. Damage to the inferior alveolar nerve can occur when the twist drill or implant encroaches, transects, or lacerates the nerve. Over penetration of the drill (drill slippage) can be triggered by the low resistance of the spongy bone [22]. It was mentioned above that Başa and Dilek [29] assessed the risk of perforation of the mandibular canal by implant drill using density and thickness parameters. They investigated whether the resistance of the bone surrounding the mandibular canal had sufficient density and thickness to avoid perforation by implant drills. The results showed the risk of inferior alveolar nerve injury can be avoided by accurately determine the bone mass around the canal and avoid use excessive force when approaching the canal. Furthermore, Wadu et al. [93], studying mandibular canal appearance on the panoramic radiographs, found that the number of cases of radio-opaque border was either disrupted or even absent. The superior border was more prone to disruption than the inferior border. It is evident that low resistance of the spongy mandibular bone and absence of mandibular canal superior wall is inauspicious anatomical combination which can lead to inferior alveolar nerve injury.

Juodzbalys et al. [87] showed that in $25 \%$ cases $(n=4)$ implant drill was identified as etiological factor with 2 cases caused by drill slippage during osteotomy preparation. The inferior alveolar nerve may be affected by perforation of the mandibular canal during drilling, or positioning the implant close to the canal and the subsequent formation of an adjacent hematoma that presses against the nerve [으. Khawaja and Renton [90] indicated that "cracking" of the inferior alveolar nerve canal roof by its close proximity to preparation of the implant bed (millimetres) may cause haemorrhage into the canal or deposition of debris which may compress and cause ischemia of the nerve.

Limited evidence exists with regard to the proper distance between the implant and the mandibular canal to ensure the nerve's integrity and physiologic activity. The proper distance should come from evaluation of clinical data as well as from biomechanical analyses [91,92]. Sammartino et al. [91] created a numeric mandibular model based on the boundary element method to simulate a mandibular segment containing a threaded fixture so that the pressure on the trigeminal nerve, as induced by the occlusal loads, could be assessed. They found that the nerve pressure increased rapidly with a bone density decrease. A low mandibular cortical bone density caused a major nerve pressure increase. In conclusion, they suggested a distance of $1.5 \mathrm{~mm}$ to prevent implant damage to the underlying inferior alveolar nerve when biomechanical loading was taken into consideration.

\section{Aesthetic considerations}

It is generally agreed that implant success criteria should include an aesthetic component [94]. Although implant success, as measured through fixture osseointegration and restoration of function, is high, the procedures available to create aesthetic implant "success" are not always predictable [20]. To ensure optimal aesthetic implant rehabilitation, the following prerequisites are considered essential: adequate bone volume (horizontal, vertical, and, contour), optimal implant position (mesiodistal, apicocoronal, buccolingual, and angulation), stable and healthy periimplant soft tissues, aesthetic soft tissues contours, and ideal emergence profile $[20,95]$. The level of bone support and the soft tissue dimensions around the implantsupported single-tooth restoration are factors suggested to be important for the aesthetic outcome of implant therapy [96]. It has been demonstrated that presence or absence of bone crest influences the appearance of papillae between implants and adjacent teeth [97]. Furthermore, the implant-supported restoration should be in symmetry with the adjacent dentition [98].

The parameters of three-dimensional optimal implant position was defined by several authors $[\underline{20}, \underline{94}, \underline{99}, \underline{100}]$. Mesio-distal dimension between adjacent teeth should be 6 to $9 \mathrm{~mm}$ to ensure minimal $(1.5 \mathrm{~mm})$ distance between implant fixture and adjacent teeth $[99,100]$. Vela et al. [101] showed that it is possible to place platformswitched implant $1 \mathrm{~mm}$ from teeth while maintaining the bone level adjacent to them. Apicocoronal implant position should be $2 \mathrm{~mm}$ below the adjacent cervicoenamel line [94]. Natural buccal and proximal restorative contour can be ensured by correctly orienting the implant in a buccolingual position - 3 to $4 \mathrm{~mm}$ from outside buccal flange [20]. Minimum $2 \mathrm{~mm}$ of space should be maintained on the buccal side in front of the external implant collar surface.

It is necessary to mention that recommendations for successful results ideally require at least $1 \mathrm{~mm}$ of bone surrounding each implant [102].

\section{Classification system of the jawbone anatomy in endosseous dental implant treatment and assessments}

New classification system of the jawbone anatomy in endosseous dental implant treatment is suggested taking into consideration previous Juodzbalys and Raustia [14] classification and literature review results (Figure 1) (Table 1). Surgical dental implant installation requires understanding of associated anatomical structures. Planning should be done on three-dimensional edentulous jaw segment (EJS) pattern (Figure 2). 


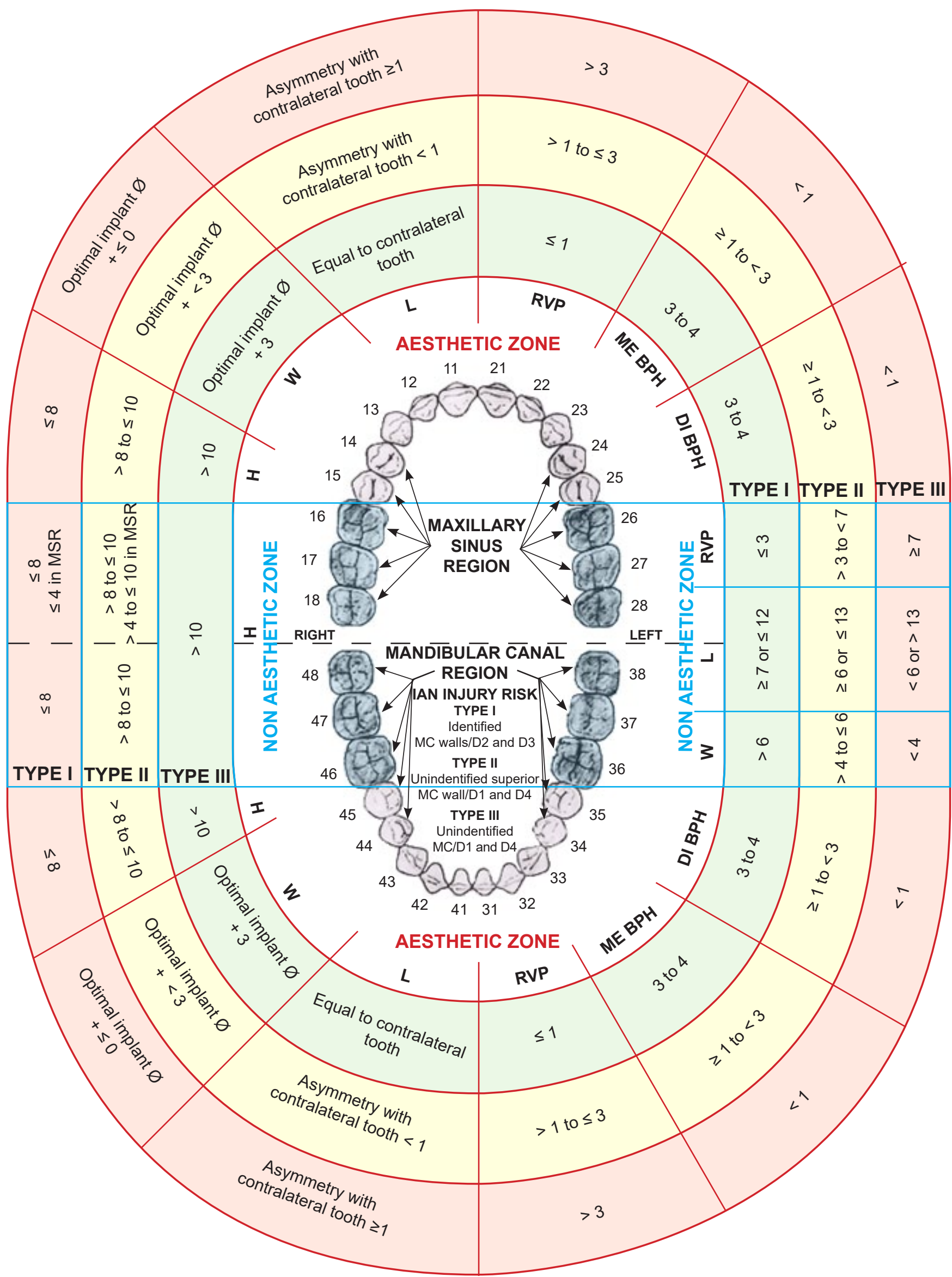

Figure 1. Classification system of the jawbone anatomy in endosseous dental implant treatment. $\mathrm{H}=$ height; $\mathrm{W}=$ width; $\mathrm{L}=$ length; $\mathrm{RVP}=$ Alveolar ridge vertical position; ME BPH = Mesial interdental bone peak height; DI BPH = Distal interdental bone peak height; $\mathrm{MC}=$ mandibular canal; IAN = inferior alveolar nerve; $\mathrm{MSR}=$ maxillary sinus region (all linear measurements are expressed in mm). 
Table 1. Classification system of the jawbone anatomy in endosseous dental implant treatment

\begin{tabular}{|c|c|c|c|c|}
\hline \multirow{2}{*}{\multicolumn{2}{|c|}{ Edentulous jaw segment parameters }} & \multicolumn{3}{|c|}{ Edentulous jaw segment types (risk degree) } \\
\hline & & $\begin{array}{c}\text { Type I } \\
\text { (low risk) }\end{array}$ & \multirow{2}{*}{\begin{tabular}{|c|c|} 
& $\begin{array}{c}\text { Type II } \\
\text { (moderate risk) }\end{array}$ \\
tic zone
\end{tabular}} & $\begin{array}{c}\text { Type III } \\
\text { (high risk) }\end{array}$ \\
\hline \multicolumn{4}{|c|}{ Non aesthetic zone } & \\
\hline \multirow[t]{2}{*}{ Height (mm) } & Maxilla & $>10$ & $\begin{array}{c}>8 \text { to } \leq 10 \\
>4 \text { to } \leq 10 \text { in MSR }\end{array}$ & $\begin{aligned} & \leq 8 \\
\leq 4 & \text { in MSR }\end{aligned}$ \\
\hline & Mandible & $>10$ & $>8$ to $\leq 10$ & $\leq 8$ \\
\hline \multicolumn{2}{|l|}{ Width (mm) } & $>6$ & $>4$ to $\leq 6$ & $<4$ \\
\hline \multicolumn{2}{|l|}{ Length (mm) } & $\geq 7$ or $\leq 12$ & $\geq 6$ or $\leq 13$ & $<6$ or $>13$ \\
\hline \multicolumn{2}{|c|}{ Alveolar ridge vertical position $(\mathrm{mm})$} & $\leq 3$ & $>3$ to $<7$ & $\geq 7$ \\
\hline \multicolumn{5}{|c|}{ Aesthetic zone } \\
\hline \multirow[t]{2}{*}{ Height (mm) } & Maxilla & $>10$ & $\begin{array}{c}>8 \text { to } \leq 10 \\
>4 \text { to } \leq 10 \text { in } \mathbf{M S R}\end{array}$ & $\begin{array}{c}\leq 8 \\
\leq 4 \text { in MSR }\end{array}$ \\
\hline & Mandible & $>10$ & $>8$ to $\leq 10$ & $\leq 8$ \\
\hline \multicolumn{2}{|l|}{ Width (mm) } & Optimal implant diameter +3 & Optimal implant diameter $+<3$ & Optimal implant diameter $+\leq 0$ \\
\hline \multicolumn{2}{|l|}{ Length (mm) } & Equal to contralateral tooth & $\begin{array}{l}\text { Asymmetry with contralateral } \\
\text { tooth }<1\end{array}$ & $\begin{array}{l}\text { Asymmetry with contralateral } \\
\text { tooth } \geq 1\end{array}$ \\
\hline \multicolumn{2}{|c|}{ Alveolar ridge vertical position $(\mathrm{mm})$} & $\leq 1$ & $>1$ to $\leq 3$ & $>3$ \\
\hline \multirow{2}{*}{$\begin{array}{c}\text { Interdental bone peak } \\
\text { height }(\mathrm{mm})\end{array}$} & Mesial & 3 to 4 & $\geq 1$ to $<3$ & $<1$ \\
\hline & Distal & 3 to 4 & $\geq 1$ to $<3$ & $<1$ \\
\hline \multicolumn{5}{|c|}{ MC region (IAN injury risk degree) } \\
\hline \multicolumn{2}{|c|}{$\begin{array}{c}\text { MC walls identification and jawbone } \\
\text { quality type }{ }^{\text {a combination }}\end{array}$} & $\begin{array}{c}\text { Identified MC walls/D2 } \\
\text { and D3 }\end{array}$ & $\begin{array}{l}\text { Unindentified superior } \\
\text { MC wall/D1 and D4 }\end{array}$ & Unindentified MC/D1 and D4 \\
\hline
\end{tabular}

${ }^{\mathrm{a}} \mathrm{D}=$ bone quality defined according to Lekholm and Zarb (1985).

$\mathrm{MC}=$ mandibular canal; IAN = inferior alveolar nerve; $\mathrm{MSR}=$ maxillary sinus region.

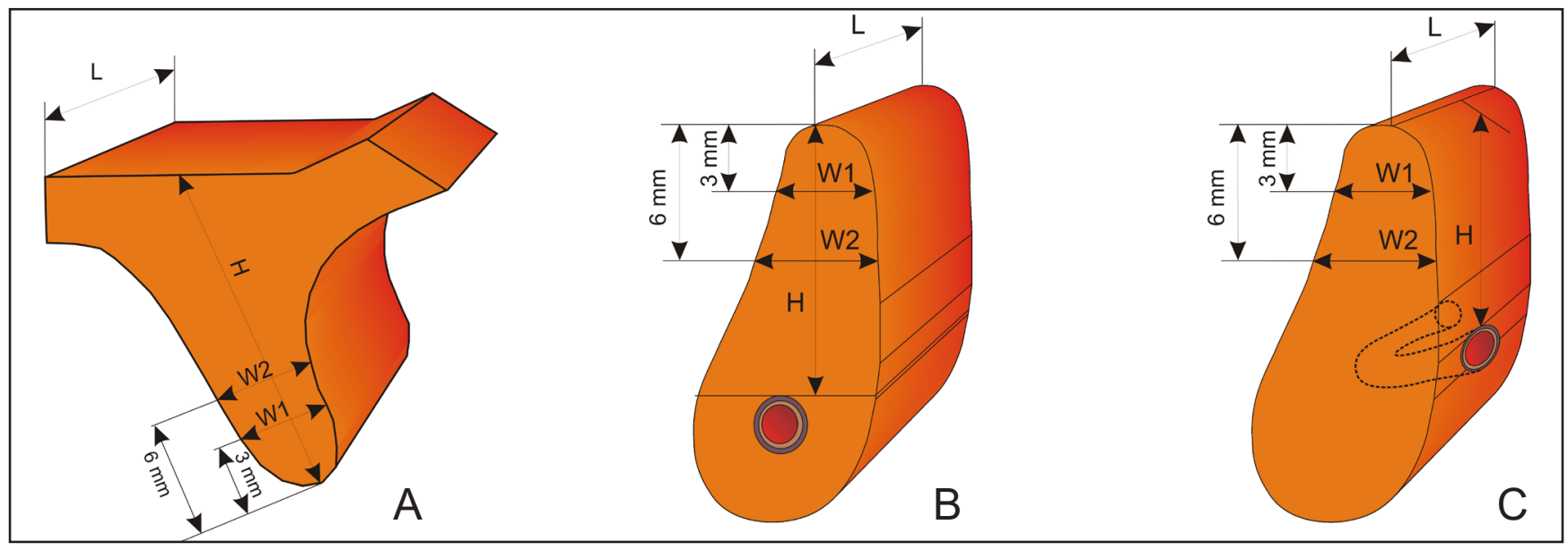

Figure 2. Edentulous jaw segments $(\mathrm{A}=$ maxillary, $\mathrm{B}$ and $\mathrm{C}=$ mandibular $)$ that consists of alveolar and basal bone. $\mathrm{A}=$ the vertical dimension $(\mathrm{H})$ of the EJS is determined by the distance between the alveolar ridge crest and maxillary sinus. $\mathrm{B}=$ the vertical dimension $(\mathrm{H})$ of the EJS is determined by the distance between the alveolar ridge crest and mandibular canal. $\mathrm{C}=$ the vertical dimension $(\mathrm{H})$ of the planned implant is determined by the distance between the alveolar crestal ridge and mental foramen. The horizontal EJS dimensions: length (L) in all cases is determined by the distance between neighbouring teeth or implants and width (W) is determined by the alveolar process width measured at the level of $3 \mathrm{~mm}$ (W1) and $6 \mathrm{~mm}$ (W2) from the crest of alveolar process.

This is because the EJS consists of alveolar and basal bone. In addition, EJS describes planned implant bed relation to present anatomical borders such as mandibular or maxillary vital structures. This is in coincidence with Ribeiro-Rotta et al. [23], they proposed that each implant site should be assessed and characterized knowing that bone characteristics vary within the same jaw [103]. All measurements should be obtained clinically and from CBCT and panoramic radiographic images. It should be done by identifying and depicting anatomical landmarks and position of important vital structures, when planning for dental implant operation. 
There are two zones distinguished in the new classification system - aesthetic and non aesthetic and two regions - mandibular canal and maxillary sinus. EJSs are attributed to aesthetic and non aesthetic mandibular or maxillary zone, because the demands and risks of aesthetic result achievement differ significantly in aesthetic zone in comparison with non aesthetic zone. Mandibular canal and maxillary sinus regions are important because of the risk of injury of inferior alveolar nerve and maxillary sinus and implant operation planning peculiarities. Furthermore, all EJSs are divided into types (Types I to III) according to their assessment result and risk degree of planned surgical treatment success. This is in coincidence with Friberg et al. [104], they suggested that the justification for assessing jawbone tissue in endosseous dental implant treatment should be diagnostic tool to assess whether the jawbone tissue is sufficient for implant treatment and a prognostic tool to predict the probability of success or failure.

The minimal dimensions of EJS for proper implantation were estimated according to the principles of threaded implant insertion.

\section{Non aesthetic zone}

The height of the alveolar process $(\mathbf{H})$ : the distance between the crest of the alveolar process and the important vital structures of the jaws (maxillary sinus, mandibular canal, mental foramen, anterior loop of mental nerve). Several factors should be considered when estimating the minimal height of an alveolar process. In some cases the crest of alveolar process is thin and it is necessary to reduce it, so it can have wider base for the planned implant installation. In such cases, the heights of EJS will be shortened by 1 to $3 \mathrm{~mm}$; this reduction had to be considered when calculating the available bone height [105] (Figure 3). If the operation is planned according to the orthopantomograph, implantation in the areas of the mandibular canal mandated that the apices should be at least $2 \mathrm{~mm}$ away from those vital structures. A minimum of $1 \mathrm{~mm}$ is demanded if the operation is planned with CBCT [106]. Essentially, the minimal height of the Type I EJS is $>10 \mathrm{~mm}$ (Figures 4A, B). EJS with the less height of $>8$ to $\leq 10 \mathrm{~mm}$ (Figure $4 \mathrm{C}$ ) and $>4$ to $\leq 10 \mathrm{~mm}$ in maxillary sinus region (Figure 4D) were considered to be Type II. However, such height was found to be sufficient to ensure primary stability of implants [14]. Simultaneous implantation with vertical alveolar process augmentation or sinus floor augmentation is recommended. If EJS height was less than $\leq 8 \mathrm{~mm}$ and $\leq 4 \mathrm{~mm}$ in maxillary sinus region was categorized as Type III (Figures 4E, F.). These measurements were

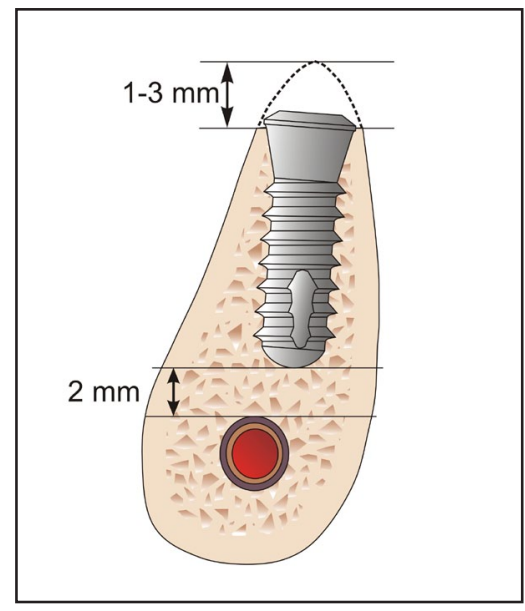

Figure 3. Thin crestal ridge was reduced to create wide recipient bed for planned implant installation. In such cases, the heights of EJSs would have been shortened by 1 to $3 \mathrm{~mm}$ at least.

considered to be insufficient for $8 \mathrm{~mm}$ length implant installation and primary stability achievement even in maxillary sinus region. Vertical alveolar process and/ or sinus floor augmentation and late implantation are recommended.

The width of alveolar process $(W)$ : determined by the alveolar process width measured at the level of 3 $\mathrm{mm}(\mathrm{W} 1)$ and $6 \mathrm{~mm}$ (W2) from the crest of alveolar process. The smallest measurement should be accepted as the width of the EJS. Recommendations for successful results ideally require at least $1 \mathrm{~mm}$ of bone surrounding each implant [102]. Most implant systems require bone widths of 5 to $7 \mathrm{~mm}[\underline{12}, \underline{102}]$. We estimated that for proper implantation the minimal width of an EJS (Type I) should be $6 \mathrm{~mm}$ (Figure 5A). Alveolar processes with widths of $>4$ to $\leq 6 \mathrm{~mm}$ were deemed insufficient (Type II) for proper implantation (Figure 5B). Despite such deficiencies, it is expected that the wider parts of the implants will be covered by bone after insertion and that primary stability would be achieved. Simultaneous implantation with alveolar process horizontal augmentation is recommended. EJS which width is less than $4 \mathrm{~mm}$ is categorized as Type III (Figure 5C). These measurements are considered to be insufficient for primary stability of implants. Horizontal alveolar process augmentation and late implantation is recommended.

The length of the EJS $(L)$ : is determined by the distance between equators of neighbouring teeth or implants. The minimal distance between 2 implants should be at least $3 \mathrm{~mm}$ [107], and minimal distances between implants and natural roots should be at least $1.5 \mathrm{~mm}$ [108] or in case of platform-switched implant $1 \mathrm{~mm}$ [101]. Considering that the optimal recommended diameter of implants in distal jaws segments is 4 to $5 \mathrm{~mm}$, all EJS of Type I should be $\geq 7$ or $\leq 12 \mathrm{~mm}$ in length (Figure 6). 

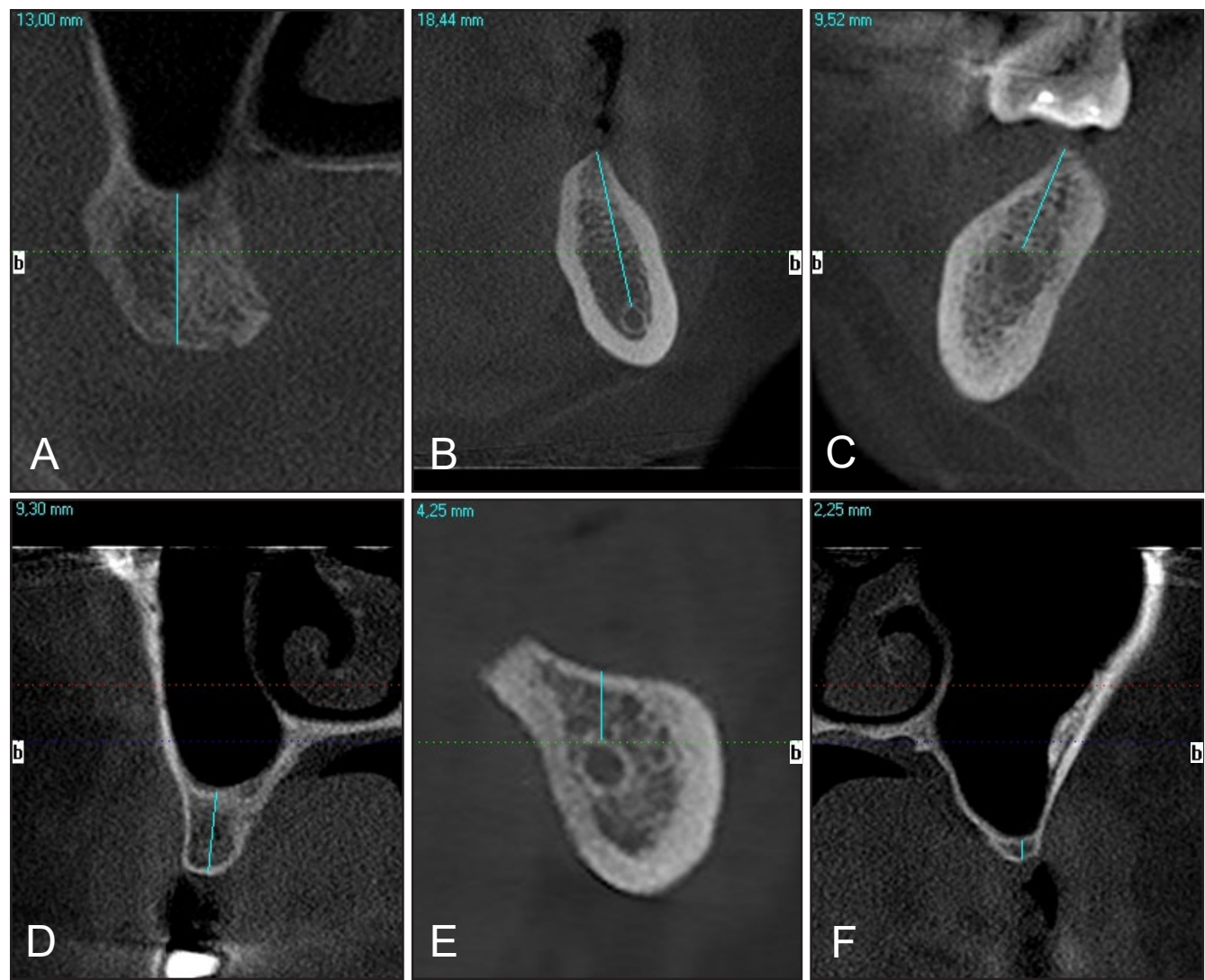

Figure 4. $\mathrm{A}=$ Upper jaw first right molar EJS on CBCT cross-sectional image is more than $10 \mathrm{~mm}$ in height and classified as Type I with no requirement of vertical alveolar process bone height augmentation prior endosseous dental implant treatment (all CBCT images in this article were obtained with I-CAT ${ }^{\circledR}$ (Imaging Sciences International LLC, Hatfield, PA USA) CBCT, a letter "b" on cross-sectional CBCT image means buccal side).

$\mathrm{B}=$ Type I height $(>10 \mathrm{~mm})$ of lower jaw first left molar EJS on CBCT cross-sectional image.

$\mathrm{C}=$ Type II height $(>8$ to $\leq 10 \mathrm{~mm})$ of lower right first molar EJS on CBCT cross-sectional image. Simultaneous implantation with sinus floor augmentation are recommended.

$\mathrm{D}=$ Type II height $(>4$ to $\leq 10 \mathrm{~mm}$ ) of upper right first molar EJS on CBCT cross-sectional image. Simultaneous implantation with vertical alveolar process augmentation are recommended.

$\mathrm{E}=$ Type III height $(\leq 8 \mathrm{~mm})$ of lower left second molar EJS on CBCT cross-sectional image. Vertical alveolar process augmentation and late implantation are recommended. Mandibular canal walls have proper identification with D2 bone quality.

$\mathrm{F}=$ Type III height $(\leq 4 \mathrm{~mm})$ of upper left premolar EJS on CBCT cross-sectional image. Sinus floor augmentation and late implantation are recommended.
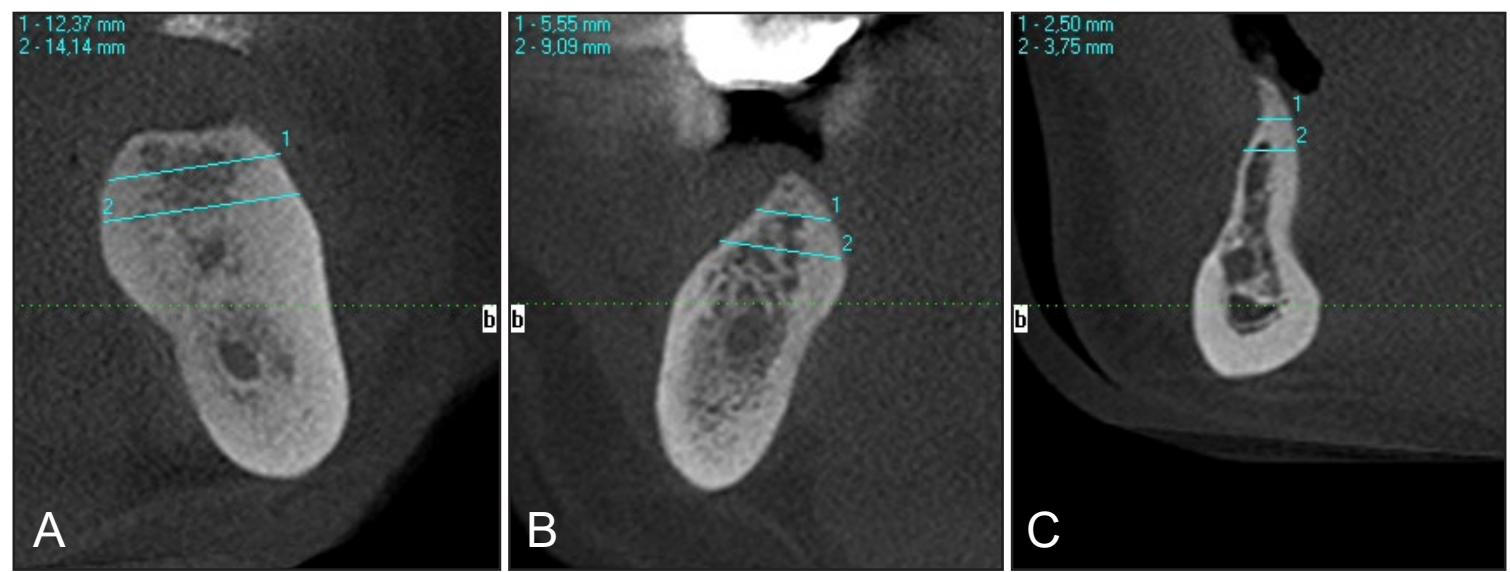

Figure 5. $\mathrm{A}=$ Type I width $(>6 \mathrm{~mm})$ of lower molar EJS on CBCT cross-sectional image at the level of $3 \mathrm{~mm}$ and $6 \mathrm{~mm}$ with no requirement of horizontal alveolar process augmentation prior endosseous dental implant treatment.

$\mathrm{B}=$ Type II width $(>4$ to $\leq 6 \mathrm{~mm}$ ) of lower right molar EJS on CBCT cross-sectional image. Endosseous dental implant treatment with simultaneous alveolar process horizontal augmentation are recommended.

$\mathrm{C}=$ Type III width of lower premolar EJS on CBCT cross-sectional image. Horizontal alveolar process augmentation and late implantation are recommended. 


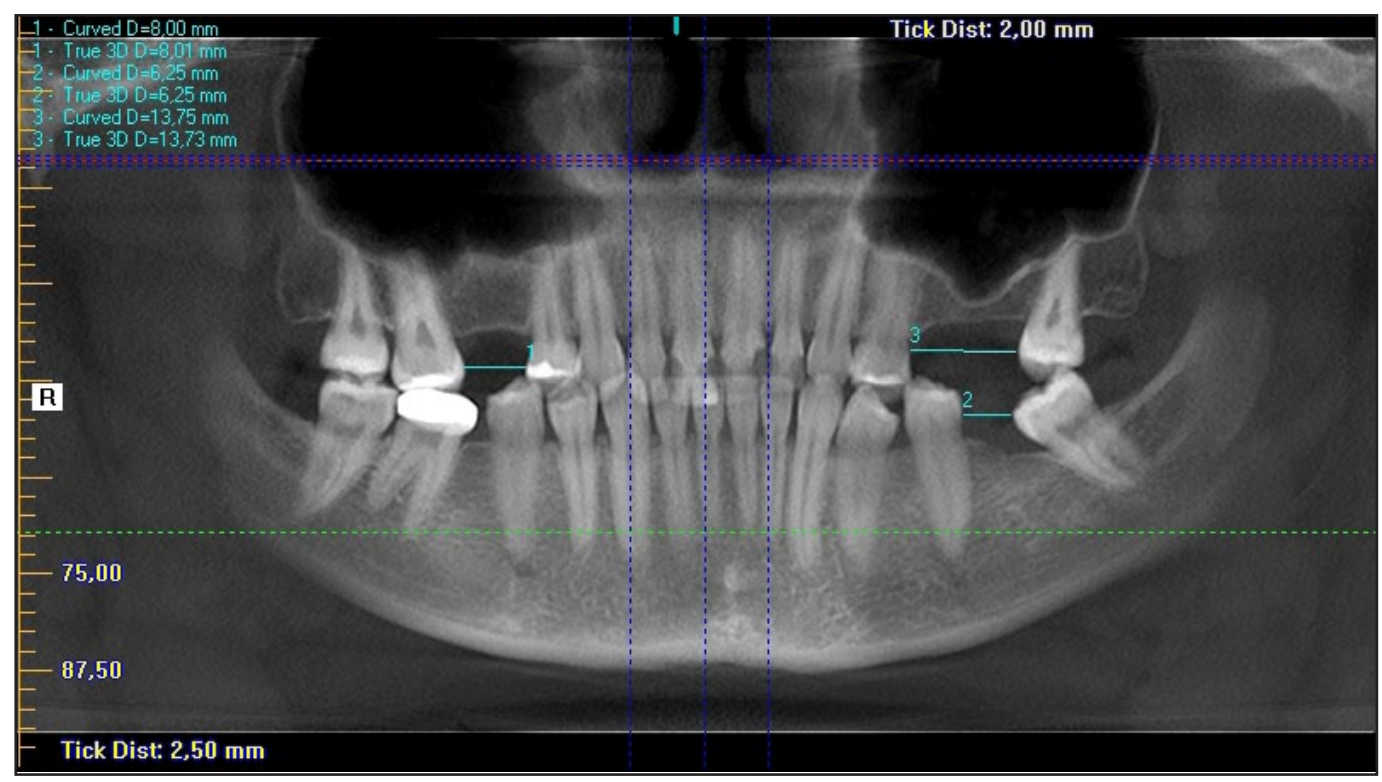

Figure 6. The length of EJS in non aesthetic zones on CBCT image (panoramic reconstruction): measurement "1" - Type I, measurement "2" - Type II, measurement "3" - Type III.

EJS which length is $\geq 6$ or $\leq 13 \mathrm{~mm}$ is considered as Type II and $<6$ or $>13 \mathrm{~mm}$ as Type III. In Type III EJS is impossible to install one or two proper diameter implants. Orthodontic treatment prior to implant treatment is recommended.

Alveolar ridge vertical position (RVP): the distance between the lowest point of alveolar ridge crest to the labial/buccal surface cervicoenamel line of the adjacent teeth. This parameter is important for achieving of favourable implant/crown length ratio and adequate aesthetic result. Adequate distance for Type I EJS is estimated to be $\leq 3 \mathrm{~mm}$. The alveolar ridge vertical position $>3$ to $<7 \mathrm{~mm}$ is defined as Type II EJS. In case when EJS height is sufficient for implant primary stability achievement, simultaneous implantation with vertical alveolar process augmentation or sinus floor augmentation and vertical alveolar process augmentation is recommended (Figure 7). The alveolar ridge vertical position $\geq 7 \mathrm{~mm}$ is defined as Type III EJS with high risk of implant treatment success due to doubtful primary stability achievement. For Type III EJS vertical alveolar process augmentation and late implantation are recommended.

\section{Aesthetic zone}

The height of the alveolar process $(\mathrm{H})$ : the distance between the crest of the alveolar process and the important vital structures of the jaws (nasal sinus floor, mental foramen, anterior loop of mental nerve). To facilitate a better implant/crown ratio, the minimal dental implant length in the aesthetic zone is $10 \mathrm{~mm}$ [109]. Hence, the alveolar process height for Type I EJS should be $>10 \mathrm{~mm}$ because the recommended

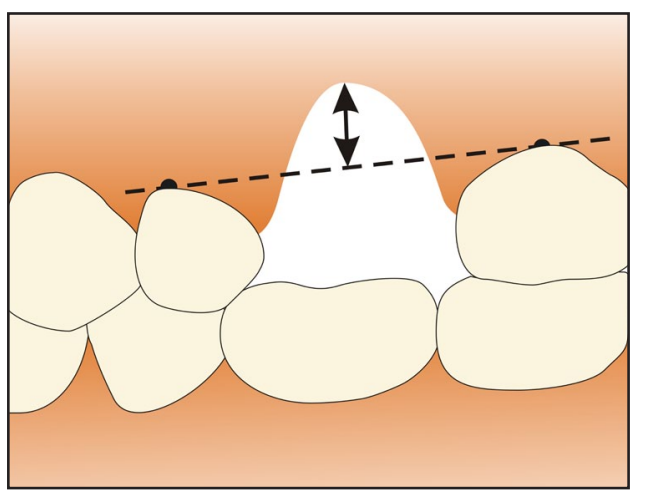

Figure 7. Alveolar ridge vertical position in non aesthetic zone: the distance between the lowest point of alveolar ridge crest to the cervicoenamel line of the adjacent teeth.

apicocoronal position of the dental implant is $2 \mathrm{~mm}$ below the adjacent cementoenamel junction [94]. A height for the alveolar process of $>8$ to $\leq 10 \mathrm{~mm}$ and $>4$ to $\leq 10 \mathrm{~mm}$ in maxillary sinus region is defined as Type II EJS. Simultaneous implantation with vertical alveolar process augmentation or sinus floor augmentation is recommended. Alveolar process height $\leq 8$ and $\leq 4 \mathrm{~mm}$ in maxillary sinus region is defined as Type III EJS. These measurements were considered to be insufficient for $8 \mathrm{~mm}$ length implant installation and primary stability achievement even in maxillary sinus region. Vertical alveolar process and/or sinus floor augmentation and late implantation are recommended.

The width of alveolar process (W): determined by the alveolar process width measured at the level of $3 \mathrm{~mm}$ (W1) and $6 \mathrm{~mm}$ (W2) from the crest of alveolar process. The smallest measurement should be accepted as the width of the EJS. It was taken into consideration that optimal implant diameter indicated 
for implantation in aesthetic zone can vary depending on tooth type and measurements. To make presented herein classification system more universal, it was considered to indicate proper alveolar process width for Type I EJS, as calculation of optimal implant diameter $+3 \mathrm{~mm}$ of the alveolar bone. It was mentioned above that it should be minimum $1 \mathrm{~mm}$ of bone surrounding each implant [102]. Hence, $3 \mathrm{~mm}$ in this case means that implant will be surrounded by minimum $1.5 \mathrm{~mm}$ of bone in buccal and lingual regions. The width of the alveolar process - optimal implant diameter $+<3 \mathrm{~mm}$ is defined as Type II EJS, and optimal implant diameter $+\leq 0 \mathrm{~mm}$ is defined as Type III EJS. For Type II EJS simultaneous implantation with alveolar process horizontal augmentation is recommended. For Type III EJS horizontal alveolar process augmentation and late implantation is recommended.

The length of the EJS (L): is determined by the least distance between neighbouring teeth or implants. The minimal distance between 2 implants should be at least $3 \mathrm{~mm}$ [107], and minimal distances between implants and natural roots should be at least $1.5 \mathrm{~mm}$ [108] or in case of platform-switched implant $1 \mathrm{~mm}$ [101]. To ensure optimal aesthetic implant rehabilitation, the implant-supported restoration should be in symmetry with the adjacent dentition [98]. Consequently, Type I EJS width must be equal to contralateral tooth. The alveolar process length characterised as asymmetry $<1 \mathrm{~mm}$ in comparison with contralateral tooth is defined as Type II EJS. Asymmetry $\geq 1 \mathrm{~mm}$ in comparison with contralateral tooth is defined as Type III EJS. In cases of Type II and III EJSs treatment choice depends on patient's aesthetic demands. If patient wish to have adequate aesthetic result, orthodontic treatment for EJS length optimisation should be recommended prior to dental implant surgical placement.

Alveolar ridge vertical position (RVP): the distance between the lowest point of alveolar ridge crest to the cervicoenamel line of the adjacent teeth. This parameter is important for achieving of implant-supported restoration length equability to contralateral tooth (Figure 8). Adequate distance for Type I EJS is estimated to be $\leq 1 \mathrm{~mm}$. The alveolar ridge vertical position $>1$ to $\leq 3 \mathrm{~mm}$ is defined as Type II EJS and distance $>3 \mathrm{~mm}$ is defined as Type III EJS. Simultaneous implantation with vertical alveolar process augmentation in case of Type II EJS is recommended. For Type III EJS vertical alveolar process augmentation and late implantation are recommended.

Mesial and distal interdental bone peak height (BPH): the distance from the tip of the interdental bone peak to the alveolar crest midline. Distances of 3 to $4 \mathrm{~mm}, \geq 1$ to $<3 \mathrm{~mm}$, and $<1 \mathrm{~mm}$ were defined as Types I, II and III, respectively (Figure 9). A study [97] demonstrated that the presence or absence of a bone crest influences the appearance of papillae between implants and adjacent teeth.

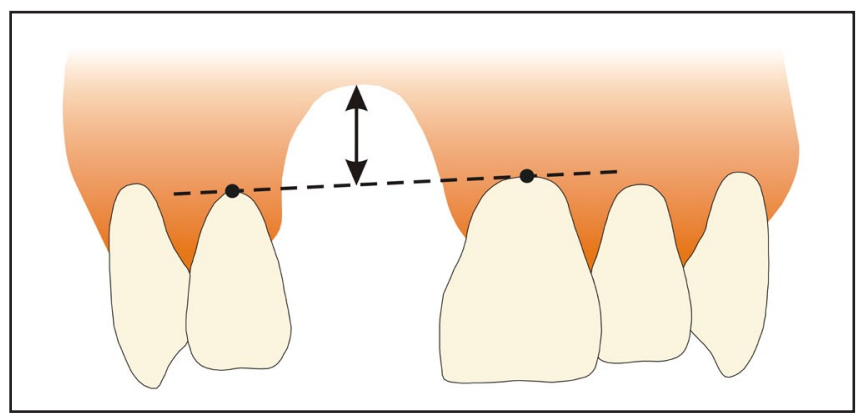

Figure 8. Alveolar ridge vertical position in aesthetic zone: the distance between the lowest point of alveolar ridge crest to the cervicoenamel line of the adjacent teeth.

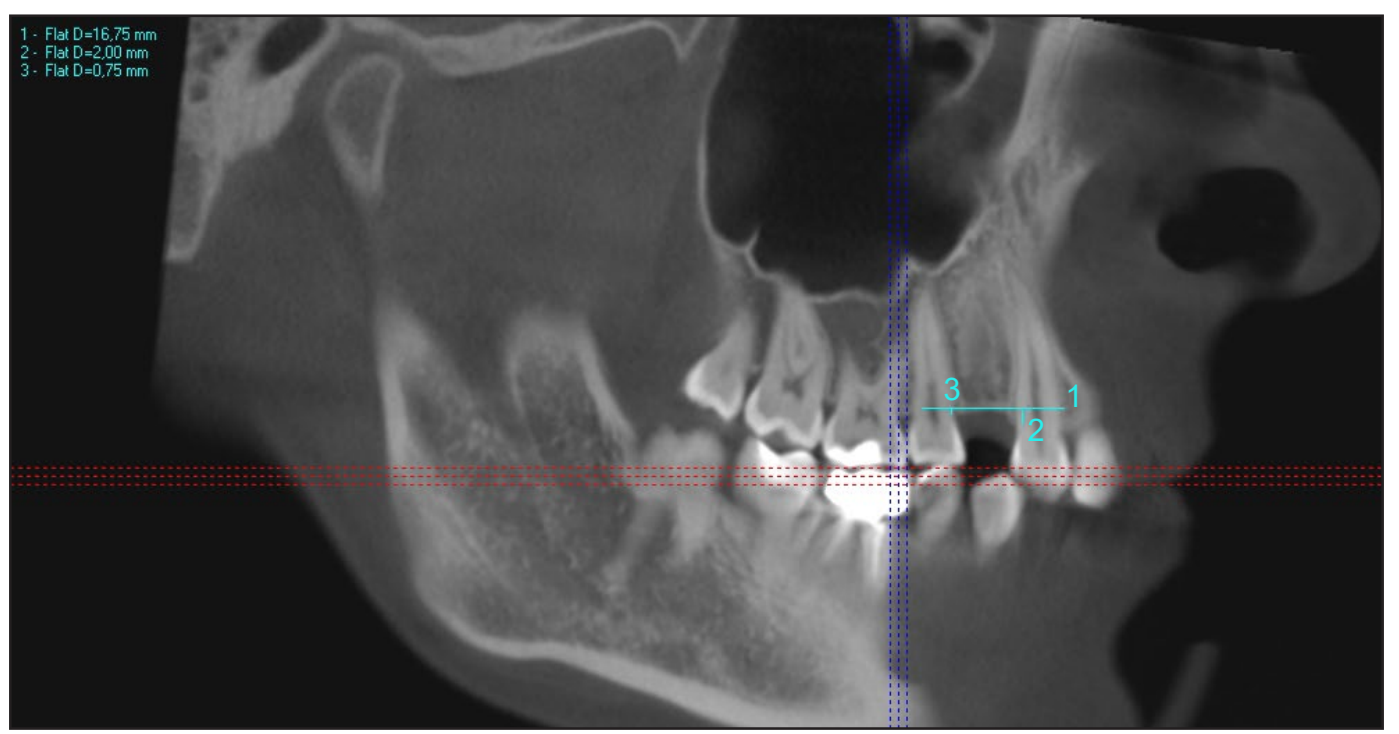

Figure 9. Type II (measurement “2”) and Type III (measurement “3”) bone peak heights of the first upper premolar EJS on CBCT image reconstruction. 
Mandibular canal walls (MCW) and jawbone quality (JBQ) type identification: mandibular canal walls are depicted on panoramic radiographs or CBCT images as radio-opaque white lines which are flanking a dark ribbon. The bone quality types are characterised according to Lekholm and Zarb classification [12] (Figures 10A - D). The combination of identified MC walls and D2 or D3 bone quality types indicates Type I
EJS with low risk of inferior alveolar nerve injury. In case when it is impossible to identify superior MC wall on X-ray and there is registered D1 or D4 bone quality type, Type II EJS with moderate inferior alveolar nerve injury risk is defined. The high inferior alveolar nerve injury risk and Type III EJS is considered when it is impossible to identify MC (Figure 11) and bone quality is registered as D1 or D4 type.
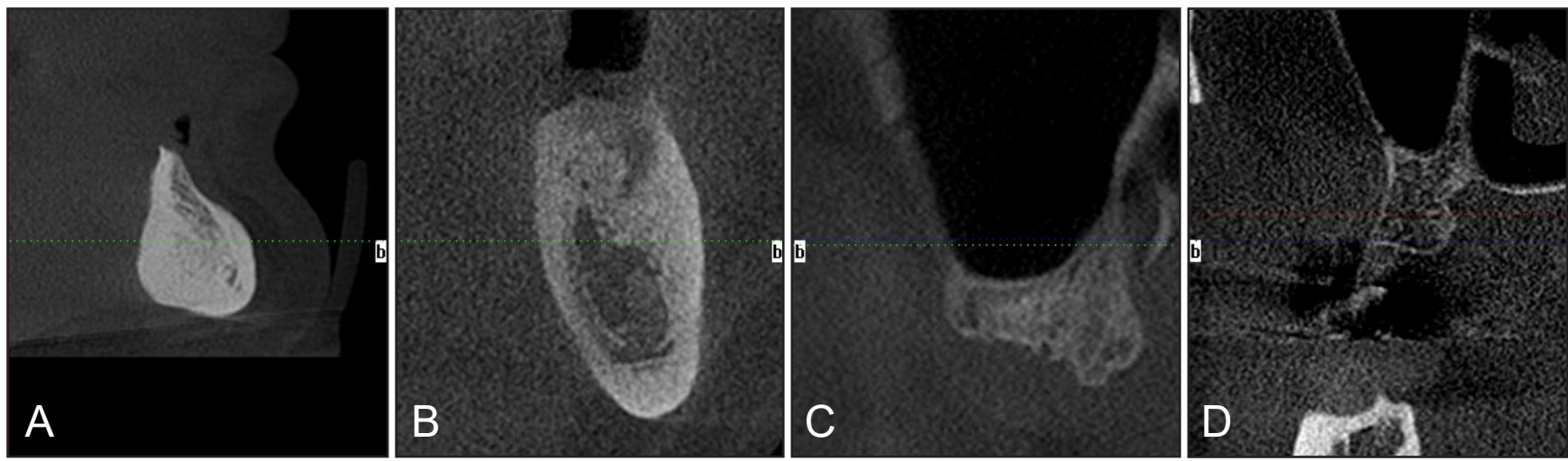

Figure 10. Bone quality according to Lekholm and Zarb classification.

$\mathrm{A}=\mathrm{D} 1$ on the CBCT cross-sectional image (mental region EJS); $\mathrm{B}=\mathrm{D} 2$ on the CBCT cross-sectional image (36 tooth EJS); $\mathrm{C}=\mathrm{D} 3$ in the EJS of upper second molar (CBCT cross-sectional image); D = D4 in the EJS of 17 tooth on CBCT cross-sectional image.

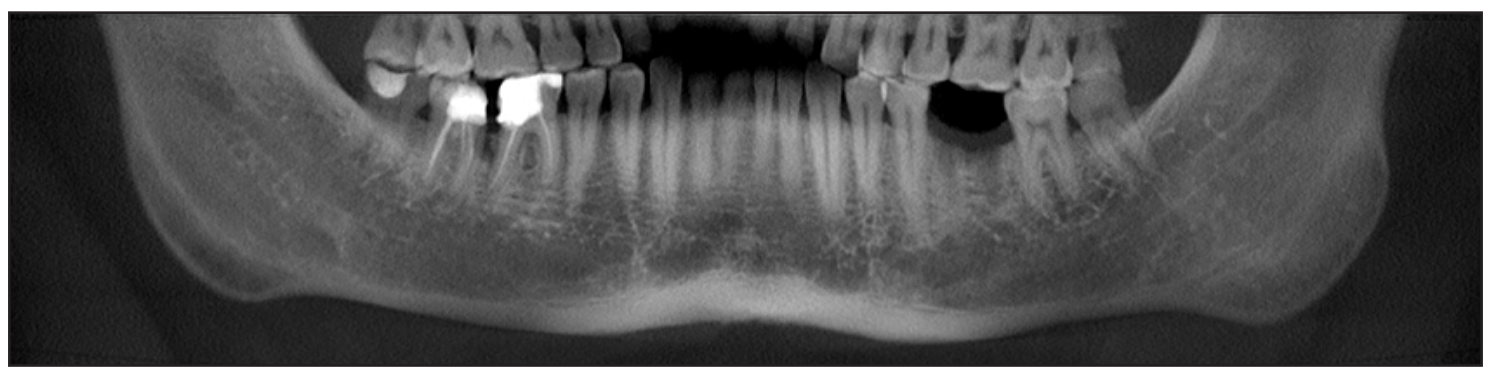

Figure 11. The part of reconstructed panoramic radiograph with unidentified superior MC wall in the EJS of 36 tooth (the same CBCT as Figure 10B).

\section{CONCLUSIONS}

New classification system of the jawbone anatomy in endosseous dental implant treatment, based on three-dimensional edentulous jaw segment pattern, is suggested. It is evident that the demands and risks of aesthetic result achievement differ significantly in aesthetic zone in comparison with non aesthetic zone. Mandibular canal and maxillary sinus regions are important anatomical vital structures of the jaws, because of the risk of injury of inferior alveolar nerve and maxillary sinus and implant operation planning peculiarities. In a result, two zones - aesthetic and non aesthetic and two regions - mandibular canal and maxillary sinus are distinguished in the new classification system. Finally edentulous jaw segments are divided into three types (Types I to III) according to their assessment result and risk degree of planned surgical treatment success. The classification system proposed here based on anatomical and radiological jawbone quantity and quality evaluation is a helpful tool for planning of treatment strategy and collaboration among specialists. Further clinical studies should be conducted for new classification validation and reliability evaluation.

\section{ACKNOWLEDGMENTS AND DISCLOSURE STATEMENTS}

The authors report no conflicts of interest related to this study. 


\section{REFERENCES}

1. The glossary of prosthodontic terms. J Prosthet Dent. 2005 Jul;94(1):10-92. [Medline: 16080238] [doi: 10.1016/j.prosdent.2005.03.013]

2. Tallgren A. The continuing reduction of the residual alveolar ridges in complete denture wearers: a mixedlongitudinal study covering 25 years. J Prosthet Dent. 1972 Feb;27(2):120-32. [Medline: 4500507] [doi: 10.1016/0022-3913(72)90188-6]

3. Esposito M, Hirsch JM, Lekholm U, Thomsen P. Biological factors contributing to failures of osseointegrated oral implants. (II). Etiopathogenesis. Eur J Oral Sci. 1998 Jun;106(3):721-64. [Medline: 9672097] [doi: 10.1046/j.0909-8836..t01-6-.x]

4. Oikarinen K, Raustia AM, Hartikainen M. General and local contraindications for endosseal implants--an epidemiological panoramic radiograph study in 65-year-old subjects. Community Dent Oral Epidemiol. 1995 Apr;23(2):114-8. [Medline: $\underline{7781299}$ ]

5. Atwood DA. Reduction of residual ridges: a major oral disease entity. J Prosthet Dent. 1971 Sep;26(3):266-79. [Medline: 4934947] [doi: 10.1016/0022-3913(71)90069-2]

6. Mercier P, Lafontant R. Residual alveolar ridge atrophy: classification and influence of facial morphology. J Prosthet Dent. 1979 Jan;41(1):90-100. [Medline: 281529] [doi: 10.1016/0022-3913(79)90363-9]

7. Seibert JS. Reconstruction of deformed, partially edentulous ridges, using full thickness onlay grafts. Part I. Technique and wound healing. Compend Contin Educ Dent. 1983 Sep-Oct;4(5):437-53. [Medline: 6578906]

8. Allen EP, Gainza CS, Farthing GG, Newbold DA. Improved technique for localized ridge augmentation. A report of 21 cases. J Periodontol. 1985 Apr;56(4):195-9. [Medline: 2987473] [doi: 10.1902/jop.1985.56.4.195]

9. Cawood JI, Howell RA. A classification of the edentulous jaws. Int J Oral Maxillofac Surg. 1988 Aug;17(4):232-6. [Medline: 3139793] [doi: 10.1016/S0901-5027(88)80047-X]

10. Eufinger H, Gellrich NC, Sandmann D, Dieckmann J. Descriptive and metric classification of jaw atrophy. An evaluation of 104 mandibles and 96 maxillae of dried skulls. Int J Oral Maxillofac Surg. 1997 Feb;26(1):23-8. [Medline: 9081248] [doi: 10.1016/S0901-5027(97)80841-7]

11. Meyer U, Vollmer D, Runte C, Bourauel C, Joos U. Bone loading pattern around implants in average and atrophic edentulous maxillae: a finite-element analysis. J Craniomaxillofac Surg. 2001 Apr;29(2):100-5. [Medline: 11465432]

12. Lekholm U, Zarb GA. In: Patient selection and preparation. Tissue integrated prostheses: osseointegration in clinical dentistry. Branemark PI, Zarb GA, Albrektsson T, editor. Chicago: Quintessence Publishing Company; 1985. p. 199-209.

13. Jensen O. Site classification for the osseointegrated implant. J Prosthet Dent. 1989 Feb;61(2):228-34. [Medline: 2654368] [doi: 10.1016/0022-3913(89)90380-6]

14. Juodzbalys G, Raustia AM. Accuracy of clinical and radiological classification of the jawbone anatomy for implantation--a survey of 374 patients. J Oral Implantol. 2004;30(1):30-9. [Medline: 15008452] [doi: 10.1563/1548-1336(2004)030<0030:AOCARC $>2.0 . C O ; 2]$

15. Kilic C, Kamburoğlu K, Ozen T, Balcioglu HA, Kurt B, Kutoglu T, Ozan H. The position of the mandibular canal and histologic feature of the inferior alveolar nerve. Clin Anat. 2010 Jan;23(1):34-42. [Medline: 19918867] [doi: $10.1002 / \mathrm{ca} .20889$ ]

16. de Oliveira-Santos C, Souza PH, de Azambuja Berti-Couto S, Stinkens L, Moyaert K, Rubira-Bullen IR, Jacobs R. Assessment of variations of the mandibular canal through cone beam computed tomography. Clin Oral Investig. 2012 Apr;16(2):387-93. Epub 2011 Mar 30. [Medline: 21448636] [doi: 10.1007/s00784-011-0544-9]

17. Chen JC, Lin LM, Geist JR, Chen JY, Chen CH, Chen YK. A retrospective comparison of the location and diameter of the inferior alveolar canal at the mental foramen and length of the anterior loop between American and Taiwanese cohorts using CBCT. Surg Radiol Anat. 2013 Jan;35(1):11-8. Epub 2012 Jun 5. [Medline: 22669484] [doi: 10.1007/s00276-012-0986-z]

18. Scarfe WC, Farman AG. Cone-Beam Computed Tomography, In: White SC, Pharoah MJ, editors. Oral Radiology Principles and Interpretation. St Louis: CV Mosby Company; 2009. p. 225-43.

19. Misch CE, Judy KW. Classification of partially edentulous arches for implant dentistry. Int J Oral Implantol. 1987;4(2):713. [Medline: 3269839$]$

20. Kazor CE, Al-Shammari K, Sarment DP, Misch CE, Wang HL. Implant plastic surgery: a review and rationale. J Oral Implantol. 2004;30(4):240-54. Review. [Medline: 15453224] [doi: 10.1563/0.637.1]

21. Bianchi AE, Sanfilippo F. Single-tooth replacement by immediate implant and connective tissue graft: a 1-9-year clinical evaluation. Clin Oral Implants Res. 2004 Jun;15(3):269-77. [Medline: 15142088] [doi: 10.1111/j.1600-0501.2004.01020.x]

22. Worthington P. Injury to the inferior alveolar nerve during implant placement: a formula for protection of the patient and clinician. Int J Oral Maxillofac Implants. 2004 Sep-Oct;19(5):731-4. [Medline: 15508990]

23. Ribeiro-Rotta RF, Lindh C, Pereira AC, Rohlin M. Ambiguity in bone tissue characteristics as presented in studies on dental implant planning and placement: a systematic review. Clin Oral Implants Res. 2011 Aug;22(8):789-801. Epub 2010 Dec 2. Review. [Medline: 21121957] [doi: 10.1111/j.1600-0501.2010.02041.x]

24. Bergkvist G, Koh KJ, Sahlholm S, Klintström E, Lindh C. Bone density at implant sites and its relationship to assessment of bone quality and treatment outcome. Int J Oral Maxillofac Implants. 2010 Mar-Apr;25(2):321-8. [Medline: 20369091] 
25. Trisi P, Rao W. Bone classification: clinical-histomorphometric comparison. Clin Oral Implants Res. 1999 Feb;10(1):1-7. [Medline: 10196784]

26. Misch CE. Bone density: A key determinant for clinical success. In: Misch CE, editor. Contemporary Implant Dentistry, 2nd ed. St Louis: CV Mosby Company; 1999. p. 109-18.

27. Norton MR, Gamble C. Bone classification: an objective scale of bone density using the computerized tomography scan. Clin Oral Implants Res. 2001 Feb;12(1):79-84. [Medline: 11168274] [doi: 10.1034/j.1600-0501.2001.012001079.x]

28. Naitoh M, Kurosu Y, Inagaki K, Katsumata A, Noguchi T, Ariji E. Assessment of mandibular buccal and lingual cortical bones in postmenopausal women. Oral Surg Oral Med Oral Pathol Oral Radiol Endod. 2007 Oct;104(4):545-50. Epub 2007 Aug 6. [Medline: 17689117] [doi: 10.1016/j.tripleo.2007.04.034]

29. Başa O, Dilek OC. Assessment of the risk of perforation of the mandibular canal by implant drill using density and thickness parameters. Gerodontology. 2011 Sep;28(3):213-20. Epub 2010 Mar 4. [Medline: 20236331]

30. Theisen FC, Shultz RE, Elledge DA. Displacement of a root form implant into the mandibular canal. Oral Surg Oral Med Oral Pathol. 1990 Jul;70(1):24-8. [Medline: 2196504] [doi: 10.1016/0030-4220(90)90172-O]

31. Fanuscu MI, Chang TL. Three-dimensional morphometric analysis of human cadaver bone: microstructural data from maxilla and mandible. Clin Oral Implants Res. 2004 Apr;15(2):213-8. [Medline: 15008933] [doi: 10.1111/j.1600-0501.2004.00969.x]

32. Schwarz MS, Rothman SL, Rhodes ML, Chafetz N. Computed tomography: Part I. Preoperative assessment of the mandible for endosseous implant surgery. Int J Oral Maxillofac Implants. 1987 Summer;2(3):137-41. [Medline: 3481354$]$

33. Naitoh M, Hirukawa A, Katsumata A, Ariji E. Evaluation of voxel values in mandibular cancellous bone: relationship between cone-beam computed tomography and multislice helical computed tomography. Clin Oral Implants Res. 2009 May;20(5):503-6. [Medline: 19250241] [doi: 10.1111/j.1600-0501.2008.01672.x]

34. Nackaerts O, Maes F, Yan H, Couto Souza P, Pauwels R, Jacobs R. Analysis of intensity variability in multislice and cone beam computed tomography. Clin Oral Implants Res. 2011 Aug;22(8):873-9. Epub 2011 Jan 18. [Medline: 21244502] [doi: 10.1111/j.1600-0501.2010.02076.x]

35. Parsa A, Ibrahim N, Hassan B, Motroni A, van der Stelt P, Wismeijer D. Influence of cone beam CT scanning parameters on grey value measurements at an implant site. Dentomaxillofac Radiol. 2013;42(3):79884780, 1-7. Epub 2012 Aug 29. [Medline: 22933535] [doi: 10.1259/dmfr/79884780]

36. van der Stelt PF. Filmless imaging: the uses of digital radiography in dental practice. J Am Dent Assoc. 2005 Oct;136(10):1379-87. [Medline: 16255462]

37. Denio D, Torabinejad M, Bakland LK. Anatomical relationship of the mandibular canal to its surrounding structures in mature mandibles. J Endod. 1992 Apr;18(4):161-5. [Medline: 1402570] [doi: 10.1016/S0099-2399(06)81411-1]

38. Benson BW, Shetty V. Dental Implants. In: White SC, Pharoah MJ, editors. Oral Radiology Principles and Interpretation. St Louis: CV Mosby Company; 2009. p. 597-612.

39. Chan HL, Misch K, Wang HL. Dental imaging in implant treatment planning. Implant Dent. 2010 Aug;19(4):288-98. [Medline: 20683285] [doi: 10.1097/ID.0b013e3181e59ebd]

40. Juodzbalys G, Wang HL. Guidelines for the Identification of the Mandibular Vital Structures: Practical Clinical Applications of Anatomy and Radiological Examination Methods. J Oral Maxillofac Res. 2010;1(2):e1. URL: http://www.ejomr.org/JOMR/archives/2010/2/e1/e1ht.htm [doi: 10.5037/jomr.2010.1201]

41. Denio D, Torabinejad M, Bakland LK. Anatomical relationship of the mandibular canal to its surrounding structures in mature mandibles. J Endod. 1992 Apr;18(4):161-5. [Medline: 1402570] [doi: 10.1016/S0099-2399(06)81411-1]

42. Phillips JL, Weller RN, Kulild JC. The mental foramen: 1. Size, orientation, and positional relationship to the mandibular second premolar. J Endod. 1990 May;16(5):221-3. [Medline: 2074415] [doi: 10.1016/S0099-2399(06)81674-2]

43. White SC, Heslop EW, Hollender LG, Mosier KM, Ruprecht A, Shrout MK; American Academy of Oral and Maxillofacial Radiology, ad hoc Committee on Parameters of Care. Parameters of radiologic care: An official report of the American Academy of Oral and Maxillofacial Radiology. Oral Surg Oral Med Oral Pathol Oral Radiol Endod. 2001 May;91(5): 498-511.[Medline: 11346726] [doi: 10.1067/moe.2001.114380]

44. Lindh C, Petersson A, Klinge B. Measurements of distances related to the mandibular canal in radiographs. Clin Oral Implants Res. 1995 Jun;6(2):96-103. [Medline: 7578787] [doi: 10.1034/j.1600-0501.1995.060205.x]

45. Klinge B, Petersson A, Maly P. Location of the mandibular canal: comparison of macroscopic findings, conventional radiography, and computed tomography. Int J Oral Maxillofac Implants. 1989 Winter;4(4):327-32. [Medline: 2639861]

46. Wyatt WM. Accessory mandibular canal: literature review and presentation of an additional variant. Quintessence Int. 1996 Feb;27(2):111-3. [Medline: 9063221 ]

47. Kim IS, Kim SG, Kim YK, Kim JD. Position of the mental foramen in a Korean population: a clinical and radiographic study. Implant Dent. 2006 Dec;15(4):404-11. [Medline: 17172959] [doi: 10.1097/01.id.0000243319.66845.15]

48. Juodzbalys G, Wang HL, Sabalys G. Anatomy of Mandibular Vital Structures. Part I: Mandibular Canal and Inferior Alveolar Neurovascular Bundle in relation with Dental Implantology. J Oral Maxillofac Res. 2010;1(1):e2. URL: http://www.ejomr.org/JOMR/archives/2010/1/e2/e2ht.htm [doi: 10.5037/jomr.2010.1102]

49. Yosue T, Brooks SL. The appearance of mental foramina on panoramic radiographs. I. Evaluation of patients. Oral Surg Oral Med Oral Pathol. 1989 Sep;68(3):360-4. [Medline: 2771380] [doi: 10.1016/0030-4220(89)90224-7] 
50. Sonick M, Abrahams J, Faiella RA. A comparison of the accuracy of periapical, panoramic, and computerized tomographic radiographs in locating the mandibular canal. Int J Oral Maxillofac Implants. 1994;9:455-460.

51. Kuzmanovic DV, Payne AG, Kieser JA, Dias GJ. Anterior loop of the mental nerve: a morphological and radiographic study. Clin Oral Implants Res. 2003 Aug;14(4):464-71. [Medline: 12869009] [doi: 10.1034/j.1600-0501.2003.00869.x]

52. Ngeow WC, YuzawatiY. The location of the mental foramen in a selected Malay population. J Oral Sci. 2003 Sep;45(3):171-5. [Medline: 14650583] [doi: 10.2334/josnusd.45.171]

53. Jacobs R, Mraiwa N, Van Steenberghe D, Sanderink G, Quirynen M. Appearance of the mandibular incisive canal on panoramic radiographs. Surg Radiol Anat. 2004 Aug;26(4):329-33. [Medline: 15197490] [doi: 10.1007/s00276-004-0242-2]

54. Jacobs R, Mraiwa N, vanSteenberghe D, Gijbels F, Quirynen M. Appearance, location, course, and morphology of the mandibular incisive canal: an assessment on spiral CT scan. Dentomaxillofac Radiol. 2002 Sep;31(5):322-7. [Medline: 12203132] [doi: 10.1038/sj.dmfr.4600719]

55. Peker I, Alkurt MT, Michcioglu T. The use of 3 different imaging methods for the localization of the mandibular canal in dental implant planning. Int J Oral Maxillofac Implants. 2008 May-Jun;23(3):463-70. [Medline: 18700369]

56. Rouas P, Nancy J, Bar D. Identification of double mandibular canals: literature review and three case reports with CT scans and cone beam CT. Dentomaxillofac Radiol. 2007 Jan;36(1):34-8. [Medline: 17329586] [doi: 10.1259/dmfr/27374727]

57. Claeys V, Wackens G. Bifid mandibular canal: literature review and case report. Dentomaxillofac Radiol. 2005 Jan;34(1):55-8. [Medline: $\underline{15709108]}$ [doi: 10.1259/dmfr/23146121]

58. Sanchis JM, Pe-arrocha M, Soler F. Bifid mandibular canal. J Oral Maxillofac Surg. 2003 Apr;61(4):422-4. [Medline: 12684957] [doi: 10.1053/joms.2003.50004]

59. Naitoh M, Hiraiwa Y, Aimiya H, Ariji E. Observation of bifid mandibular canal using cone-beam computerized tomography. Int J Oral Maxillofac Implants. 2009 Jan-Feb;24(1):155-9. [Medline: 19344041]

60. Angelopoulos C, Thomas SL, Hechler S, Parissis N, Hlavacek M. Comparison between digital panoramic radiography and cone-beam computed tomography for the identification of the mandibular canal as part of presurgical dental implant assessment. J Oral Maxillofac Surg. 2008 Oct;66(10):2130-5. [Medline: 18848113] [doi: 10.1016/j.joms.2008.06.021]

61. Lindh C, Petersson A. Radiologic examination for location of the mandibular canal: a comparison between panoramic radiography and conventional tomography. Int J Oral Maxillofac Implants. 1989 Fall;4(3):249-53. [Medline: 2639123]

62. Bou Serhal C, Jacobs R, Flygare L, Quirynen M, van Steenberghe D. Perioperative validation of localization of the mental foramen. Dentomaxillofac Radiol 2002;31:39-43. [Medline: 11803387] [doi: 10.1038/sj.dmfr.4600662]

63. Ekestubbe A, Gröndahl K, Gröndahl HG. The use of tomography for dental implant planning. Dentomaxillofac Radiol. 1997 Jul;26(4):206-13. [Medline: 9442610] [doi: 10.1038/sj.dmfr.4600249]

64. Sakakura CE, Morais JA, Loffredo LC, Scaf G. A survey of radiographic prescription in dental implant assessment. Dentomaxillofac Radiol. 2003 Nov;32(6):397-400. [Medline: 15070843] [doi: 10.1259/dmfr/20681066]

65. Lascala CA, Panella J, Marques MM. Analysis of the accuracy of linear measurements obtained by cone beam computed tomography (CBCT-NewTom). Dentomaxillofac Radiol. 2004 Sep;33(5):291-4. [Medline: 15585804] [doi: $10.1259 / \mathrm{dmfr} / 25500850$ ]

66. Sato S, Arai Y, Shinoda K, Ito K. Clinical application of a new cone-beam computerized tomography system to assess multiple two-dimensional images for the preoperative treatment planning of maxillary implants: case reports. Quintessence Int. 2004 Jul-Aug;35(7):525-8. [Medline: 15259967]

67. Almog DM, LaMar J, LaMar FR, LaMar F. Cone beam computerized tomography-based dental imaging for implant planning and surgical guidance, Part 1: Single implant in the mandibular molar region. J Oral Implantol. 2006;32(2):7781. [Medline: 16704109] [doi: $10.1563 / 789.1]$

68. Loubele M, Guerrero ME, Jacobs R, Suetens P, van Steenberghe D. A comparison of jaw dimensional and quality assessments of bone characteristics with cone-beam CT, spiral tomography, and multi-slice spiral CT. Int J Oral Maxillofac Implants. 2007 May-Jun;22(3):446-54. [Medline: 17622012]

69. Arai Y, Tammisalo E, Iwai K, Hashimoto K, Shinoda K. Development of a compact computed tomographic apparatus for dental use. Dentomaxillofac Radiol. 1999 Jul;28(4):245-8. [Medline: 10455389] [doi: 10.1038/sj.dmfr.4600448]

70. Mozzo P, Procacci C, Tacconi A, Martini PT, Andreis IA. A new volumetric CT machine for dental imaging based on the cone-beam technique: preliminary results. Eur Radiol. 1998;8(9):1558-64. [Medline: 9866761] [doi: $10.1007 / \mathrm{s} 003300050586$ ]

71. Delcanho RE. Neuropathic implications of prosthodontic treatment. J Prosthet Dent. 1995 Feb;73(2):146-52. Review. [Medline: 7722929] [doi: 10.1016/S0022-3913(05)80154-4]

72. Rubenstein JE, Taylor TD. Apical nerve transection resulting from implant placement: a 10-year follow-up report. J Prosthet Dent. 1997 Dec;78(6):537-41. [Medline: 9421779] [doi: 10.1016/S0022-3913(97)70001-5]

73. Wismeijer D, van Waas MA, Vermeeren JI, Kalk W. Patients' perception of sensory disturbances of the mental nerve before and after implant surgery: a prospective study of 110 patients. Br J Oral Maxillofac Surg. 1997 Aug;35(4):254-9. [Medline: 9291263] [doi: 10.1016/S0266-4356(97)90043-7]

74. Dao TT, Mellor A. Sensory disturbances associated with implant surgery. Int J Prosthodont 1998 Sep-Oct;11(5):462-9. Review. [Medline: 9922738] 
75. Bartling R, Freeman K, Kraut RA. The incidence of altered sensation of the mental nerve after mandibular implant placement. J Oral Maxillofac Surg. 1999 Dec;57(12):1408-12. [Medline: 10596660] [doi: 10.1016/S0278-2391(99)90720-6]

76. Walton JN. Altered sensation associated with implants in the anterior mandible: a prospective study. J Prosthet Dent. 2000 Apr;83(4):443-9. [Medline: 10756294] [doi: 10.1016/S0022-3913(00)70039-4]

77. Ziccardi VB, Assael LA. Mechanisms of trigeminal nerve injuries. Atlas Oral Maxillofac Surg Clin North Am. 2001 Sep;9(2):1-11. [Medline: 11665372]

78. von Arx T, Häfliger J, Chappuis V. Neurosensory disturbances following bone harvesting in the symphysis: a prospective clinical study. Clin Oral Implants Res. 2005 Aug;16(4):432-9. [Medline: 16117767] [doi: 10.1111/j.1600-0501.2005.01138.x ]

79. Abarca M, van Steenberghe D, Malevez C, De Ridder J, Jacobs R. Neurosensory disturbances after immediate loading of implants in the anterior mandible: an initial questionnaire approach followed by a psychophysical assessment. Clin Oral Investig. 2006 Dec;10(4):269-77. Epub 2006 Aug 26. [Medline: 16937108] [doi: 10.1007/s00784-006-0065-0]

80. Greenstein G, Tarnow D. The mental foramen and nerve: clinical and anatomical factors related to dental implant placement: a literature review. J Periodontol. 2006 Dec;77(12):1933-43. Review. [Medline: 17209776] [doi: 10.1902/jop.2006.060197]

81. Hegedus F, Diecidue RJ. Trigeminal nerve injuries after mandibular implant placement--practical knowledge for clinicians. Int J Oral Maxillofac Implants. 2006 Jan-Feb;21(1):111-6. Review. [Medline: 16519189]

82. Tay AB, Zuniga JR. Clinical characteristics of trigeminal nerve injury referrals to a university centre. Int J Oral Maxillofac Surg. 2007 Oct;36(10):922-7. Epub 2007 Sep 17. [Medline: 17875382] [doi: 10.1016/j.ijom.2007.03.012]

83. Misch CE. Root form surgery in the edentulous anterior and posterior mandible: Implant insertion. In: Misch CE, editor. Contemporary Implant Dentistry. St. Louis, MO: Mosby Elsevier; 2008. p. 221-6.

84. Alhassani AA, AlGhamdi AS. Inferior alveolar nerve injury in implant dentistry: diagnosis, causes, prevention, and management. J Oral Implantol. 2010;36(5):401-7. Epub 2010 Jun 14. Review. [Medline: 20545547] [doi: 10.1563/AAID-JOI-D-09-00059]

85. Misch CE, Resnik R. Mandibular nerve neurosensory impairment after dental implant surgery: management and protocol. Implant Dent. 2010 Oct;19(5):378-86. [Medline: 20881808] [doi: 10.1097/ID.0b013e3181effa92]

86. Juodzbalys G, Wang HL, Sabalys G. Injury of the Inferior Alveolar Nerve during Implant Placement: a Literature Review. J Oral Maxillofac Res. 2011;2(1):e1. URL: http:/www.ejomr.org/JOMR/archives/2011/1/e1/v2n1e1ht.htm [doi: $10.5037 /$ jomr.2011.2101]

87. Juodzbalys G, Wang HL, Sabalys G, Sidlauskas A, Galindo-Moreno P. Inferior alveolar nerve injury associated with implant surgery. Clin Oral Implants Res. 2013 Feb;24(2):183-90. Epub 2011 Nov 1. [Medline: 22092662] [doi: $10.1111 / \mathrm{j} .1600-0501.2011 .02314 . x$ ]

88. Kraut RA, Chahal O. Management of patients with trigeminal nerve injuries after mandibular implant placement. J Am Dent Assoc. 2002 Oct;133(10):1351-4. [Medline: 12403537]

89. Lamas Pelayo J, Pe-arrocha Diago M, Martí Bowen E, Pe-arrocha Diago M. Intraoperative complications during oral implantology. Med Oral Patol Oral Cir Bucal. 2008 Apr 1;13(4):E239-43. Review. [Medline: 18379448]

90. Khawaja N, Renton T. Case studies on implant removal influencing the resolution of inferior alveolar nerve injury. Br Dent J. 2009 Apr 11;206(7):365-70. [Medline: 19357667] [doi: 10.1038/sj.bdj.2009.258]

91. Sammartino G, Marenzi G, Citarella R, Ciccarelli R, Wang HL. Analysis of the occlusal stress transmitted to the inferior alveolar nerve by an osseointegrated threaded fixture. J Periodontol. 2008 Sep;79(9):1735-44. [Medline: 18771376] [doi: 10.1902/jop.2008.080030]

92. Guan H, van Staden R, Loo YC, Johnson N, Ivanovski S, Meredith N. Influence of bone and dental implant parameters on stress distribution in the mandible: a finite element study. Int J Oral Maxillofac Implants. 2009 Sep-Oct;24(5):866-76. [Medline: 19865627]

93. Wadu SG, Penhall B, Townsend GC. Morphological variability of the human inferior alveolar nerve. Clin Anat. 1997;10(2):82-7. [Medline: 9058013] [doi: 10.1002/(SICI)1098-2353(1997)10:2<82::AID-CA2>3.0.CO;2-V]

94. Saadoun AP, Landsberg TC. Treatment classifications and sequencing for post extraction implant therapy: A review. Pract Periodontics Aesthet Dent. 1997;9:933-941. [Medline: 9573848]

95. Jovanovic SA. Bone rehabilitation to achieve optimal aesthetics. Pract Periodontics Aesthet Dent. 1997 Jan-Feb;9(1):41-51; quiz 52. [Medline: 9550059$]$

96. Belser UC, Buser D, Hess D, Schmid B, Bernard JP, Lang NP. Aesthetic implant restorations in partially edentulous patients--a critical appraisal. Periodontol 2000. 1998 Jun;17:132-50. Review. [Medline: 10337321] [doi: 10.1111/j.1600-0757.1998.tb00131.x]

97. Choquet V, Hermans M, Adriaenssens P, Daelemans P, Tarnow DP, Malevez C. Clinical and radiographic evaluation of the papilla level adjacent to single-tooth dental implants. A retrospective study in the maxillary anterior region. $\mathrm{J}$ Periodontol. 2001 Oct;72(10):1364-71. [Medline: 11699478] [doi: 10.1902/jop.2001.72.10.1364]

98. Fürhauser R, Florescu D, Benesch T, Haas R, Mailath G, Watzek G. Evaluation of soft tissue around single-tooth implant crowns: the pink esthetic score. Clin Oral Implants Res. 2005 Dec;16(6):639-44. [Medline: 16307569] [doi: $10.1111 / \mathrm{j} .1600-0501.2005 .01193 . \mathrm{x}]$ 
99. Ohrnell LO, Hirsch JM, Ericsson I, Brånemark PI. Single-tooth rehabilitation using osseointegration. A modified surgical and prosthodontic approach. Quintessence Int. 1988 Dec;19(12):871-6. [Medline: 3254544]

100. Adell R, Eriksson B, Lekholm U, Brånemark PI, Jemt T. Long-term follow-up study of osseointegrated implants in the treatment of totally edentulous jaws. Int J Oral Maxillofac Implants. 1990 Winter;5(4):347-59. [Medline: 2094653]

101. Vela X, Méndez V, Rodríguez X, Segalá M, Tarnow DP. Crestal bone changes on platform-switched implants and adjacent teeth when the tooth-implant distance is less than $1.5 \mathrm{~mm}$. Int J Periodontics Restorative Dent. 2012 Apr;32(2):149-55. [Medline: 22292143]

102. Allen F, Smith DG. An assessment of the accuracy of ridge-mapping in planning implant therapy for the anterior maxilla. Clin Oral Implants Res. 2000 Feb;11(1):34-8. [Medline: 11168191] [doi: 10.1034/j.1600-0501.2000.011001034.x]

103.Lindh C, Obrant K, Petersson A. Maxillary bone mineral density and its relationship to the bone mineral density of the lumbar spine and hip. Oral Surg Oral Med Oral Pathol Oral Radiol Endod. 2004 Jul;98(1):102-9. [Medline: 15243479] [doi: 10.1016/S1079-2104(03)00460-8]

104.Friberg B, Jemt T, Lekholm U. Early failures in 4,641 consecutively placed Brånemark dental implants: a study from stage 1 surgery to the connection of completed prostheses. Int J Oral Maxillofac Implants. 1991 Summer;6(2):142-6. [Medline: $\underline{1809668]}$

105. Hardwick R, Scantlebury TV, Sanchez R, Whitely N, Ambruster J. Membrane design criteria for guided bone regeneration of the alveolar ridge. In: Buser D, Dahlin C, Schenk RK, editors. Guided bone regeneration in implant dentistry. Hong Kong: Quintessence; 1994: p. b101-36.

106. Dula K, Mini R, van der Stelt PF, Buser D. The radiographic assessment of implant patients: decision-making criteria. Int J Oral Maxillofac Implants. 2001 Jan-Feb;16(1):80-9. [Medline: 11280366]

107. Hobo S, Ichida E, Garcia LT. Osseointegration and Occlusal Rehabilitation, 1st ed. Chicago, Ill: Quintessence; 1989. p. 35 .

108. Bauman GR, Mills M, Rapley JW, Hallmon WH. Clinical parameters of evaluation during implant maintenance. Int J Oral Maxillofac Implants. 1992 Summer;7(2):220-7. Review. [Medline: 1398839]

109.Davies SJ, Gray RJ, Young MP. Good occlusal practice in the provision of implant borne prostheses. Br Dent J. 2002 Jan 26;192(2):79-88. Review. [Medline: 11841055] [doi: 10.1038/sj.bdj.4801298]

\section{To cite this article:}

Juodzbalys G, Kubilius M. Clinical and Radiological Classification of the Jawbone Anatomy in Endosseous Dental Implant Treatment.

J Oral Maxillofac Res 2013;4(2):e2

URL: http://www.ejomr.org/JOMR/archives/2013/2/e2/v4n2e2ht.pdf

doi: $10.5037 /$ jomr.2013.4202

Copyright (C) Juodzbalys G, Kubilius M. Accepted for publication in the JOURNAL OF ORAL \& MAXILLOFACIAL RESEARCH (http://www.ejomr.org), 12 June 2013.

This is an open-access article, first published in the JOURNAL OF ORAL \& MAXILLOFACIAL RESEARCH, distributed under the terms of the Creative Commons Attribution-Noncommercial-No Derivative Works 3.0 Unported License, which permits unrestricted non-commercial use, distribution, and reproduction in any medium, provided the original work and is properly cited. The copyright, license information and link to the original publication on (http://www.ejomr.org) must be included. 